\title{
Effect of Biostimulants on Several Physiological Characteristics and Chlorophyll Content in Broccoli under Drought Stress and Re-watering
}

\author{
Alina KAŁUŻEWICZ*, Włodzimierz KRZESIŃSKI, \\ Tomasz SPIŻEWSKI, Anna ZAWORSKA
}

\author{
Poznań University of Life Sciences, Faculty of Horticulture and Landscape Architecture, Department of Vegetable Crops, Dąbrowskiego 159, \\ 60-594 Poznań, Poland; alina.kaluzewicz@up.poznan.pl (*correspondingauthor); wlodzimierz.krzesinski@up.poznan.pl; \\ tomasz.spizewski@up.poznan.pl;anna.zaworska@up.poznan.pl
}

\begin{abstract}
Drought stress is one of the many factors that lead to decreased yield in both quality and quantity. One method to improve plant resistance to this stress is application of biostimulants. The most widely used biostimulants are protein hydrolysates, containing sea algae extract and humus compounds. In the present study, the influence of the amino acids as well as combination of amino acids with Ascophyllum nodosum filtrate on broccoli (Brassica oleracea var. italica) plants cvs. 'Agassi' and 'Tiburon' was investigated. The plants were watered with Ascophyllum nodosum filtrate three days before planting and sprayed three times with amino acids two, four and six weeks after planting. The present results show that biostimulants have a significant effect on both gas exchange and transpiration rate both prior to the application of stress, under drought stress and after re-watering. Biostimulant treatment led to an increase of drought tolerance in both studied cultivars but the final effect depended on cultivar. 'Tiburon' cultivar turned out to be more tolerant to drought stress than 'Agassi'. The application of biostimulants resulted in an increase of photosynthetic rate, stomatal conductance, internal $\mathrm{CO}_{2}$ concentration and transpiration rate in 'Agassi' cultivar under drought stress. This effect was not observed in 'Tiburon'. The chlorophyll content was higher under drought stress as compared to the value prior to stress in both cultivars.
\end{abstract}

Keywords: amino acids, Ascophyllum nodosum, Brassica oleracea var. italica, photosynthetic properties, cultivar

Abbreviations: A-net photosynthesis rate, Ci-internal $\mathrm{CO}_{2}$ concentration, E-transpiration rate, gs-stomatal conductance, PPFD-photosynthetic photon flux density, RH - relative air humidity

\section{Introduction}

Drought stress is one of the many factors that lead to a decreased yield in both quality and quantity. It affects metabolic processes and gas exchange parameters (stomatal conductance, internal $\mathrm{CO}_{2}$ concentration and permeability of cell membrane) (Yordanov et al., 2000). One of the first responses of a plant to drought stress is stomatal closing, which results in limited water loss (Galmes et al., 2007a; Rahbarian et al., 2011). Decreasing internal $\mathrm{CO}_{2}$ concentration (Ci) and inhibition of ribulose-1, 5-bisphosphate carboxylase/oxygenase enzyme activity and ATP synthesis lead to a decrease in net photosynthetic rate under drought stress (Dulai et al., 2006).

Exposure of plants to drought stress induces numerous physiological and biochemical changes resulting in a disturbance of normal growth and development (Wu et al., 2012). Strong stress leads to disruption of cell structure and metabolism which may eventually result in arrest of photosynthesis, disturbance of metabolism, and plant death (Shao et al., 2008).

One method to improve plant resistance is application of biostimulants. The biostimulants enhance abiotic stress tolerance, including tolerance to drought period (Ertani et al., 2013, Colla et al., 2015, Calvo et al., 2014). The most widely used biostimulants are protein hydrolysates, containing sea algae extract and humus compounds (Ertani et al., 2009).

Seaweeds form an integral part of marine coastal ecosystems. It has been estimated that there are about 9,000 species of macroalgae broadly classified into three main groups. (brown, red, and green algae). Brown seaweeds are the second most abundant group comprising about 2,000 species and are most commonly used in agriculture and among them Ascophyllum nodosum L. is the most researched (Ugarte et al., 2006; Hong et al., 2007). Seaweeds are used for nutrient 
198

supplements such as biostimulants or biofertilizers to increase the plant growth and yield (Khan et al., 2009).

According to Boselli et al., (2015) protein hydrolysates contributed to enhanced resistance to drought stress in grapevine. There was an increase in biomass of stems and roots, as well as sugar, phenolic compounds and anthocyanin content. Ascophyllum nodosum extract application, under mild drought stress, improved the leaf water relations and helped to maintain the cell turgor pressure and reduce stomatal closure, which resulted in a large leaf area and high photosynthetic rate, and consequently enhanced growth (Xu and Lescovar, 2015). In addition, the application of biostimulants results in increased production of antioxidants in plants, which decrease their sensitivity to stress conditions (Ertani et al., 2011). Ascophyllum nodosum affects carbon and nitrogen metabolism (Jannin et al., 2013) and it also contains osmolytes such as mannitol, which play a protective role in plants exposed to stress (Reed et al., 1985).

Furthermore, protein hydrolisates containing proline and betaine induce a secondary metabolism and enhance plant resistance to stress (Ertani $e$ t al., 2013). In addition, some of these contain a lot of enzymes, such as nitrate reductase, malate dehydrogenase, leucino-amino peptidase, phosphorilase and phosphatase, enhancing resistance of plants to stress (Maini, 2006). By stimulating the main enzyme systems, protein hydrolisates biostimulants improve utilization of nutrients in plants, consequently leading to a better plant growth.

To the best of our knowledge, there is a lack of studies regarding the physiological changes of broccoli plants following biostimulant treatment especially under stress conditions. The present study focused on determining the influence of amino acids and Ascophyllum nodosum filtrate biostimulants on several selected physiological parameters and chlorophyll content in two broccoli cultivars under drought stress, before stress and after re-watering. A description of the physiological response of broccoli to drought stress and application of biostimulants may provide a test that is both quick and practical for determining which cultivars in cultivations biostimulants will be necessary and beneficial.

\section{Materials and Methods}

\section{Plant materials and treatments}

The experiment was conducted using two broccoli cultivars 'Agassi' and 'Tiburon' in a growing chamber in 2015. These cultivars differ in the length of their growing season. 'Agasssi' belongs to the early cultivars, and 'Tiburon' belongs to a later one. The temperature was $18 / 16^{\circ} \mathrm{C}$ (day/night), photoperiod 16 hours, relative humidity $90 \%$, photosynthetic photon flux density $150 \mu \mathrm{mol} \cdot \mathrm{m}^{-2} \mathrm{~s}^{-1}$. Broccoli seedlings were produced in $0.09 \mathrm{dm}^{3}$ pots filled with peat substrate for growing cruciferous vegetables (Kronen-Klasmann). The seedlings with three-four leaves were transplanted to larger containers $\left(5 \mathrm{dm}^{3}\right)$. Before planting, minerals were supplemented to the maximum optimum level (in $\mathrm{mg} \mathrm{dm}^{-3}$ of substrate): $\mathrm{N}^{-N_{3}}$ - 250; P - 200; $\mathrm{K}$ - 600; Ca - 1600; Mg - 160 + microelements. Additionally, during the growing period the plants were fed with complex fertilisers.

The plants were watered with Ascophyllum nodosum filtrate three days before planting and sprayed three times with amino acids two, four and six weeks after planting. Drought stress occurred due to discontinuation of watering for two days (one week after last application of amino acids). The physiological measurements were noted before stress, during stress and two days after re-watering.

The level of soil water content was monitored with soil moisture probes. The water capacity of the soil was $40 \% \mathrm{v} / \mathrm{v}$ and under drought stress water content decreased to $15 \% \mathrm{v} / \mathrm{v}$.

\section{Physiologicalmeasurements}

Photosynthesis intensity (A), transpiration (E), stomatal conductance $\left(\mathrm{g}_{\mathrm{s}}\right)$, and internal $\mathrm{CO}_{2}$ concentration $\left(\mathrm{C}_{\mathrm{i}}\right)$ were measured using the LCpro + system (ADC BioScientific), which automatically set levels of $\mathrm{CO}_{2}(360 \mathrm{ppm})$, PPFD 400 $\mu \mathrm{mol} \cdot \mathrm{m}^{-2} \mathrm{~s}^{-1}, \mathrm{RH}(50 \%)$ and air temperature $\left(20^{\circ} \mathrm{C}\right)$, depending on the program selected. It enabled automatic change of parameters while taking measurements. Gas exchange was determined with a leaf chamber in LCpro+ (an area of 6.25 $\mathrm{cm}^{2}$ ). Net photosynthesis rate was automatically calculated as the difference between $\mathrm{CO}_{2}$ concentrations in the air coming in and out of the measurement chamber $\left(\mu \mathrm{mol} \cdot \mathrm{m}^{-2} \cdot \mathrm{s}^{-1}\right)$. The rate of air flow through the LCpro+ chamber was approximately 200 $\mathrm{ml} \cdot \mathrm{min}^{-1}$. The measurements were made when all the parameters were stabilised.

Relative chlorophyll content was measured with an OSI CCM-200 Plus leaf chlorophyll meter (ADC BioScientific Ltd.) on the same leaves that were used for photosynthesis measurements.

\section{Statistical analysis}

The experiment was established as a two-factor design, in four replicates (one plant in each). The significance of the biostimulants and the time of measurement (before drought stress, during stress and after re-watering) to the physiological parameters were determined with the ANOVA. Differences between the means were estimated with the Duncan test at a significance level of $\mathrm{P}=0.05$.

\section{Results and Discussion}

\section{Gas exchange and transpiration rate}

Drought stress is associated with changes in gas exchange and consequently varations in photosynthetic rate, which is directly related to yield (Subrahmanyam et al., 2006; Galmés et al., 2007b; Sikuku et al., 2010).

The results show that biostimulants have a significant effect on both gas exchange and transpiration rates both prior to the application of stress, under drought stress and after re-watering. The effect of their application depended on the cultivar (Tables 1-4). In 'Agassi' cultivar, when plants were treated with biostimulants, the photosynthetic rate (A) was significantly higher prior to and during stress, as well as after re-watering. However, in 'Tiburon' cultivar a significant influence of biostimulants on photosynthetic rate was observed only after re-watering. The increase in photosynthesis rate after biostimulant treatment is consistent with the results obtained by Pramod et al. (2000) in pepper, Mikiciuk and Dobromilska (2014) in tomato and Xu and Leskovar (2015) in spinach. The biostimulants containing protein hydrolisates affect $\mathrm{N}$ and $\mathrm{C}$ metabolism (Ertani et al., 2013). According to Colla (2015) due to the rise in photosynthesis and energy supply for cell 
metabolism generated by protein hydrolisates applications, the increase of $\mathrm{N}$ assimilation in plants may be a result of the positive effects of protein hydrolisates on the production of $\mathrm{C}$ skeletons and energy supply, which are needed for amino acid biosynthesis.

Under stress conditions, a reduction in stomatal conductance $\left(\mathrm{g}_{\mathrm{s}}\right)$ can have conservative effects because it allows the plant to save water and improve water use efficiency (Warren et al., 2004; Chaves et al., 2009). Campos et al. (2014) reported that after four-days of drought stress the $g_{s}$ value decreased by $60 \%$.

In the current research in 'Agassi' cultivar stomatal conductance of plants treated with biostimulants before stress and after re-watering almost doubled, while during stress it was almost three times higher than in plants not treated with biostimulants. In 'Tiburon' cultivar a significant increase in $\mathrm{g}_{\mathrm{s}}$ in plants treated with biostimulants as compared to control occurred prior to drought stress and after re-watering. No effect of biostimulants on $\mathrm{g}_{s}$ value was found during drought stress. The increase in $g_{s}$ after biostimulant application was in agreement with the results of the studies of Xu and Leskovar (2015). According to these authors application of Ascophyllum nodosum under drought stress in spinach resulted in an increase of approximately $71 \%$ in stomatal conductance. They concluded that Ascophyllum nodosum application improved leaf water relations and helped to maintain cell turgor pressure and reduced stomatal closure, increased photosynthetic rate, and consequently enhanced growth.

In this study, in both cultivars exposed to drought stress, the stomatal conductance decreased in all plants (Table 2). In

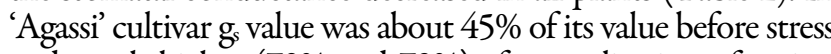
and much higher (70\% and 73\%) after application of amino acids and amino acids + Ascophyllum nodosum filtrate, respectively. In 'Tiburon' cultivar gs value was 67\%, 56\% after amino acids and $71 \%$ after amino acids + Ascophyllum nodosum filtrate application. After re-watering $\mathrm{g}_{s}$ value increased in all the plants except 'Tiburon' control plants. A considerable decrease in $\mathrm{g}_{\text {s }}$ value under drought stress followed by an increase after re-watering was also reported by Wu et al. (2012) in his study of cauliflower.

The stomatal conductance is strictly correlated with $\mathrm{CO}_{2}$ content in internal $\mathrm{CO}_{2}$ concentration $\left(\mathrm{C}_{\mathrm{i}}\right)$ (Flexas and Medrano, 2002; Zlatev and Yordanov, 2004). According to Lawlor and Tezara (2009) at the beginning of the drought stress period $\mathrm{C}_{\mathrm{i}}$ value decreases and rises during severe stress. In the current study a significant increase in $\mathrm{C}_{\mathrm{i}}$ value under stress was observed in 'Agassi' cultivar in plants untreated with biostimulants (Table 3). Using biostimulants did not cause any change in $\mathrm{C}_{\mathrm{i}}$ content in either cultivar. Lack of changes in $\mathrm{C}_{\mathrm{i}}$ value in 'Tiburon' before stress, under stress and after rewatering showed higher resistance to stress of this cultivar as compared to 'Agassi' genotype.

Stomatal closure not only leads to reduced stomatal conductance and extension of internal $\mathrm{CO}_{2}$ concentration, but also reduces the transpiration process (Souza et al., 2004; Miyashita et al., 2005; Harb et al., 2010). In the study by Mikiciuk and Dobromilska (2014) biostimulant application was found to induce a reduced transpiration rate. The results are inconsistent with the present findings, where application of biostimulants to 'Agassi' cultivar contributed to an increase in transpiration intensity both before and during stress (Table 4). This confirms the observations of Xu and Leskovar (2015), who observed a $42 \%$ increase in transpiration rate under drought stress after Ascophyllum nodosum extract was applied.

Table 1. Photosynthesis rate (A) prior to stress, under stress and after re-watering of two broccoli cultivars treated with biostimulants

\begin{tabular}{|c|c|c|c|c|}
\hline \multirow{2}{*}{ Treatment } & \multicolumn{4}{|c|}{ Photosynthesis rate $\left(\mu \mathrm{mol} \mathrm{CO}{ }_{2} \cdot \mathrm{m}^{-2} \mathrm{~s}^{-1}\right)$} \\
\hline & Prior to stress & Under stress & After re-watering & Mean \\
\hline \multicolumn{5}{|c|}{ 'Agassi' } \\
\hline Control & $9.83 c^{*}$ & $2.27 \mathrm{~d}$ & $9.15 \mathrm{c}$ & $7.08 \mathrm{~B}$ \\
\hline Amino acids & $12.30 \mathrm{ab}$ & $12.60 \mathrm{ab}$ & $11.84 \mathrm{ab}$ & $12.24 \mathrm{~A}$ \\
\hline Amino acids + Ascophyllum nodosum filtrate & $12.93 \mathrm{a}$ & $13.14 \mathrm{a}$ & $11.46 \mathrm{~b}$ & $12.51 \mathrm{~A}$ \\
\hline Mean & $11.69 \mathrm{~A}^{* *}$ & $9.34 \mathrm{C}$ & $10.82 \mathrm{~B}$ & \\
\hline \multicolumn{5}{|c|}{ 'Tiburon' } \\
\hline Control & $12.08 \mathrm{ab}$ & $12.37 \mathrm{ab}$ & $9.64 \mathrm{c}$ & $11.36 \mathrm{~B}$ \\
\hline Amino acids & $12.30 \mathrm{ab}$ & $13.47 \mathrm{a}$ & $12.37 \mathrm{ab}$ & $12.72 \mathrm{~A}$ \\
\hline Amino acids + Ascophyllum nodosum filtrate & $10.83 \mathrm{bc}$ & $12.09 \mathrm{ab}$ & $11.66 \mathrm{~b}$ & $11.53 \mathrm{~B}$ \\
\hline Mean & $11.74 \mathrm{~B}$ & $12.64 \mathrm{~A}$ & $11.23 \mathrm{~B}$ & \\
\hline
\end{tabular}

${ }^{*}$ Values marked with the same letter do not differ significantly at $\mathrm{P}=0.95$

${ }^{* *}$ Values marked with the same capital letter do not differ significantly at $\mathrm{P}=0.95$

Table 2. Stomatal conductance $\left(\mathrm{g}_{\mathrm{s}}\right)$ prior to stress, under stress and after re-watering of two broccoli cultivars treated with biostimulants

\begin{tabular}{|c|c|c|c|c|}
\hline \multirow{2}{*}{ Treatment } & \multicolumn{4}{|c|}{ Stomatal conductance $\left(\mathrm{mmol} \cdot \mathrm{m}^{-2} \cdot \mathrm{s}^{-1}\right)$} \\
\hline & Prior to stress & Under stress & After re-watering & Mean \\
\hline \multicolumn{5}{|c|}{ 'Agassi' } \\
\hline Control & $0.31 \mathrm{~d}^{*}$ & $0.14 \mathrm{e}$ & $0.36 \mathrm{~d}$ & $0.27 \mathrm{C}$ \\
\hline Amino acids & $0.64 \mathrm{ab}$ & $0.45 \mathrm{~cd}$ & $0.68 \mathrm{ab}$ & $0.59 \mathrm{~B}$ \\
\hline Amino acids + Ascophyllum nodosum filtrate & $0.74 \mathrm{a}$ & $0.54 \mathrm{bc}$ & $0.78 \mathrm{a}$ & $0.69 \mathrm{~A}$ \\
\hline Mean & $0.57 \mathrm{~A}^{* *}$ & $0.38 \mathrm{~B}$ & $0.60 \mathrm{~A}$ & \\
\hline \multicolumn{5}{|c|}{ 'Tiburon' } \\
\hline Control & $0.67 \mathrm{bc}$ & $0.45 \mathrm{~d}$ & $0.45 \mathrm{~d}$ & $0.53 \mathrm{~B}$ \\
\hline Amino acids & $0.85 \mathrm{a}$ & $0.48 \mathrm{~d}$ & $0.74 \mathrm{~b}$ & $0.69 \mathrm{~A}$ \\
\hline Amino acids + Ascophyllum nodosum filtrate & $0.60 \mathrm{c}$ & $0.43 \mathrm{~d}$ & $0.70 \mathrm{bc}$ & $0.57 \mathrm{~B}$ \\
\hline Mean & $0.71 \mathrm{~A}$ & $0.45 \mathrm{C}$ & $0.63 \mathrm{~B}$ & \\
\hline
\end{tabular}

${ }^{*}$ Values marked with the same letter do not differ significantly at $\mathrm{P}=0.95$

${ }^{* *}$ Values marked with the same capital letter do not differ significantly at $\mathrm{P}=0.95$ 
Table 3. Internal $\mathrm{CO}_{2}$ concentration $\left(\mathrm{C}_{\mathrm{i}}\right)$ prior to stress, under stress and after re-watering of two broccoli cultivars treated with biostimulants

\begin{tabular}{|c|c|c|c|c|}
\hline \multirow{2}{*}{ Treatment } & \multicolumn{4}{|c|}{ Internal $\mathrm{CO}_{2}$ concentration $(\mathrm{ppm})$} \\
\hline & Prior to stress & Under stress & After re-watering & Mean \\
\hline \multicolumn{5}{|c|}{ 'Agassi' } \\
\hline Control & $274.8 c^{*}$ & $327.4 \mathrm{a}$ & $284.3 \mathrm{bc}$ & $295.5 \mathrm{~A}$ \\
\hline Amino acids & $290.23 \mathrm{~b}$ & $285.7 \mathrm{bc}$ & $294.7 \mathrm{~b}$ & $290.2 \mathrm{~A}$ \\
\hline Amino acids + Ascophyllum nodosum filtrate & $288.5 \mathrm{bc}$ & $285.2 \mathrm{bc}$ & $298.2 \mathrm{~b}$ & $290.6 \mathrm{~A}$ \\
\hline Mean & $284.5 \mathrm{~B}^{* *}$ & $299.4 \mathrm{~A}$ & $292.4 \mathrm{~B}$ & \\
\hline \multicolumn{5}{|c|}{ ‘Tiburon' } \\
\hline Control & $289.5 \mathrm{a}$ & $286.0 \mathrm{a}$ & $294.8 \mathrm{a}$ & $290.1 \mathrm{~A}$ \\
\hline Amino acids & $297.1 \mathrm{a}$ & $285.9 \mathrm{a}$ & $297.0 \mathrm{a}$ & $293.3 \mathrm{~A}$ \\
\hline Amino acids + Ascophyllum nodosum filtrate & $304.5 \mathrm{a}$ & $283.7 \mathrm{a}$ & $294.0 \mathrm{a}$ & $294.1 \mathrm{~A}$ \\
\hline Mean & $297.0 \mathrm{~A}$ & $285.2 \mathrm{~A}$ & $295.3 \mathrm{~A}$ & \\
\hline
\end{tabular}

*Values marked with the same letter do not differ significantly at $\mathrm{P}=0.95$

${ }^{*}$ Values marked with the same capital letter do not differ significantly at $\mathrm{P}=0.95$

Table 4. Transpiration rate (E) prior to stress, under stress and after re-watering of two broccoli cultivars treated with biostimulants

\begin{tabular}{|c|c|c|c|c|}
\hline \multirow{2}{*}{ Treatment } & \multicolumn{4}{|c|}{ Transpiration rate $\left(\mathrm{mmol} \cdot \mathrm{m}^{-2} \cdot \mathrm{s}^{-1}\right)$} \\
\hline & Prior to stress & Under stress & After re-watering & Mean \\
\hline \multicolumn{5}{|c|}{ 'Agassi' } \\
\hline Control & $2.14 \mathrm{~b}^{*}$ & $0.76 \mathrm{f}$ & $1.62 \mathrm{cde}$ & $1.51 \mathrm{~B}$ \\
\hline Amino acids & $2.77 \mathrm{a}$ & $1.39 \mathrm{e}$ & $1.84 \mathrm{bcd}$ & $2.00 \mathrm{~A}$ \\
\hline Amino acids + Ascophyllum nodosum filtrate & $2.84 \mathrm{a}$ & $1.47 \mathrm{de}$ & $1.97 \mathrm{bc}$ & $2.10 \mathrm{~A}$ \\
\hline Mean & $2.58 \mathrm{~A}^{* *}$ & $1.21 \mathrm{C}$ & $1.81 \mathrm{~B}$ & \\
\hline \multicolumn{5}{|c|}{ 'Tiburon' } \\
\hline Control & $2.59 \mathrm{~b}$ & $1.31 \mathrm{e}$ & $1.67 \mathrm{~cd}$ & $1.86 \mathrm{~B}$ \\
\hline Amino acids & $3.23 \mathrm{a}$ & $1.37 \mathrm{de}$ & $1.93 \mathrm{c}$ & $2.18 \mathrm{~A}$ \\
\hline Amino acids + Ascophyllum nodosum filtrate & $2.83 \mathrm{~b}$ & $1.36 \mathrm{de}$ & $1.75 \mathrm{c}$ & $1.98 \mathrm{~B}$ \\
\hline Mean & $2.88 \mathrm{~A}$ & $1.35 \mathrm{C}$ & $1.78 \mathrm{~B}$ & \\
\hline
\end{tabular}

Values marked with the same letter do not differ significantly at $\mathrm{P}=0.95$

${ }^{* *}$ Values marked with the same capital letter do not differ significantly at $\mathrm{P}=0.95$

Table 5. Chlorophyll content prior to stress, under stress and after re-watering of two broccoli cultivars treated with biostimulants

\begin{tabular}{|c|c|c|c|c|}
\hline \multirow{2}{*}{ Treatment } & \multicolumn{4}{|c|}{ Chlorophyll content } \\
\hline & Prior to stress & Under stress & After re-watering & Mean \\
\hline \multicolumn{5}{|c|}{ 'Agassi' } \\
\hline Control & $76.9 \mathrm{~b}$ & $87.0 \mathrm{ab}$ & $45.9 \mathrm{~d}$ & $69.9 \mathrm{~B}$ \\
\hline Amino acids & $77.1 \mathrm{~b}$ & $88.7 \mathrm{a}$ & $59.0 \mathrm{c}$ & $74.9 \mathrm{AB}$ \\
\hline Amino acids + Ascophyllum nodosum filtrate & $79.5 \mathrm{ab}$ & $81.0 \mathrm{ab}$ & $78.6 \mathrm{ab}$ & $79.7 \mathrm{~A}$ \\
\hline Mean & $77.8 \mathrm{~B}$ & $85.6 \mathrm{~A}$ & $61.2 \mathrm{C}$ & \\
\hline \multicolumn{5}{|c|}{ ‘Tiburon’ } \\
\hline Control & $76.2 \mathrm{~b}$ & $91.7 \mathrm{a}$ & $77.0 \mathrm{~b}$ & $81.6 \mathrm{~A}$ \\
\hline Amino acids & $71.7 \mathrm{~b}$ & $84.2 \mathrm{ab}$ & $76.6 \mathrm{~b}$ & $77.5 \mathrm{~A}$ \\
\hline Amino acids + Ascophyllum nodosum filtrate & $79.6 \mathrm{ab}$ & $83.5 \mathrm{ab}$ & $80.9 \mathrm{ab}$ & $81.3 \mathrm{~A}$ \\
\hline Mean & $75.8 \mathrm{~B}$ & $86.5 \mathrm{~A}$ & $78.2 \mathrm{~B}$ & \\
\hline
\end{tabular}

${ }^{*}$ Values marked with the same letter do not differ significantly at $\mathrm{P}=0.95$

${ }^{*}$ Values marked with the same capital letter do not differ significantlv at $\mathrm{P}=0.95$

In 'Tiburon' cultivar a significant effect of amino acid treatment was observed only prior to stress. After re-watering the biostimulants did not affect the transpiration rate in either cultivar.

\section{Chlorophyll content}

The typical response to oxidative stress under drought is the reduction of chlorophyll content. Chlorophyll degradation and/or chlorophyll synthesis deficiency occur when plants are subjected to drought stress (Ahmed et al., 2009; Rahbarian et al., 2011; Guo et al., 2016). According to Hussein et al. (2008) drought stress resulted in chlorophyll content increase, while Farhad et al. (2011), Pirzad et al. (2011) and Ma et al. (2015) did not observe any significant changes in its content. According to Jannin et al. (2013) the beneficial influence of applying seaweed extract is due to its providing plants with many components such as phytohormones, betaines, polymers and nutrients, many of which may work synergistically. Seaweed extracts are not only a source of cytokinins, but they enhance their endogenous synthesis as well (Wally et al., 2013). Cytokinins develop protective effects on chloroplast (ZavaletaMancera et al., 2007) and consequently they affect chlorophyll content.

Many authors have pointed out a considerable chlorophyll content increase after treatment with biostmulants (Whapham et al., 1993, Spinelli et al., 2009; Thirumaran et al., 2009, Shehata et al., 2011). These are in accordance with the present findings, but only in 'Agassi' cultivar, where mean chlorophyll content was significantly higher after application amino acids + Ascophyllum nodosum filtrate.

In the present study an increase in chlorophyll content under drought stress conditions, as compared to the value prior to stress, was observed in control in 'Tiburon' cultivar and in 'Agassi' cultivar after amino acids treatment (Table 5). 
However, when both amino acids + Ascophyllum nodosum filtrate were used, the difference was insignificant. After rewatering a decrease in chlorophyll content occurred only in 'Agassi' cultivar, in both plants untreated with biostimulants and in those treated with amino acids. Following amino acids + Ascophyllum nodosum filtrate application in 'Agassi' and in 'Tiburon' cultivars no significant differences in chlorophyll content were observed, either after re-watering or before stress.

\section{Conclusions}

The present research showed that the biostimulant treatment led to an increase of drought tolerance in both studied cultivars. The application of biostimulants resulted in an increase of photosynthetic rate, stomatal conductance, internal $\mathrm{CO}_{2}$ concentration and transpiration rate in 'Agassi' cultivar under drought stress. This effect was not observed in 'Tiburon'. Chlorophyll content was higher under drought stress as compared to the value prior to stress in both cultivars.

\section{References}

Ahmed CB, Rouina BB, Sensoy S, Boukhris M, Abdallah FB (2009). Changes in gas exchange, proline accumulation and antioxidative enzyme activities in three olive cultivars under contrasting water availability regimes. Environmental and Experimental Botany 67:345-352.

Boselli M, Bahouaoui M, Lachhab N, Sanzani SM, Ippolito A (2015). Grapevine: protein hydrolysates against water stress. L'Informatore Agrario 22:39-42.

Calvo P, Nelson L, Kloepper JW (2014). Agricultural uses of plant biostimulants. Plant Soil 383:3-41.

Campos H, Trejo C, Pena-Valdivia CB, Garía-Nava R, CondeMartínez FV, Cruz-Ortega MR (2014).Stomatal and non-stomatal limitations of bell pepper (Capsicum annuum L.) plants under water stress and re-watering: Delayed restoration of photosynthesis during recovery. Environmental and Experimental Botany 98:56-64.

Chaves MM, Flexas J, Pinheiro C (2009). Photosynthesis under drought and salt stress: regulation mechanisms from whole plant to cell. Annals of Botany 103:551-560.

Colla G, Nardi S, Cardarelli M, Ertani A, Lucini L, Canaguier R, Rouphael Y (2015). Protein hydrolysates as biostimulants in horticulture. Scientia Horticulturae 196:28-38.

Dulai S, Molnar I, Pronay J, Scernak A, Tarnai R, Molnarlang M (2006). Effects of drought on photosynthetic parameters and heat stability of PSII in wheat and in Aegilops species originating from dry habitats. Acta Biologica Szegediensis 50:11-17.

Ertani A, Cavani L, Pizzeghello D, Brandellero E, Altissimo A, Ciavatta C, Nardi S (2009). Biostimulant activities of two protein hydrolysates on the growth and nitrogen metabolism in maize seedlings. Journal of Plant Nutrition and Soil Science 172:237-244.

Ertani A, Schiavon M, Altissimo A, Franceschi C, Nardi S (2011). Phenol-containing organic substances stimulate phenylpropanoid metabolism in Zea mays. Journal of Plant Nutrition and Soil Science 174(3):496-503.
Ertani A, Schiavon M, Muscolo A, Nardi S (2013). Alfalfa plant-derived biostimulant stimulate short-term growth of salt stressed Zea mays L. plants. Plant Soil 364:145-158.

Farhad MS, Babak AM, Reza ZM, Hassan RSM, Afshin T (2011). Response of proline, soluble sugars, photosynthetic pigments and antioxidant enzymes in potato (Solanum tuberosum L.) to different irrigation regimes in greenhouse condition. Australian Journal of Crop Science 5:55-60.

Flexas J, Medrano H (2002). Drought-inhibition of photosynthesis in C3 plants: stomatal and non-stomatal limitations revisited. Annals of Botany 89:183-189.

Galmés J, Abadia A, Medrano H, Flexas J (2007a). Photosynthesis and photoprotection responses to water stress in the wild-extinct plant Lysimachia minoricensis. Environmental and Experimental Botany 60(3):308-317.

Galmés J, Medrano H, Flexas J (2007b). Photosynthetic limitations in response to water stress and recovery in Mediterranean plants with different growth forms New Phytologist 175:81-93.

Guo YY, Yu HY, Kong DS, Yan F, Zhang YJ (2016). Effects of drought stress on growth and chlorophyll fluorescence of Lycium ruthenicum Murr. Seedling. Photosynthetica 54:1-7.

Harb A, Krishnan A, Madana MR, Pereira AA (2010). Molecular and physiological analysis of drought stress in Arabidopsis reveals early responses leading to acclimation in plant growth. Plant Physiology 154:1254-1271.

Hong DD, Hein HM, Son PN (2007). Seaweeds from Vietnam used for functional food, medicine and biofertilizer. Journal of Applied Phycology 19:817-826.

Hussein MM, Kassab OM, Abo Ellil AA (2008). Evaluating water stress influence on growth and photosynthetic pigments of two sugar beet varieties. Research Journal of Agriculturae and Biological Sciences 4:36-941.

Jannin L, Arkoun M, Etienne P, Laíné P, Goux D, Garnica M, Fuentes M, Francisco S, Baigorri R, Cruz F, Houdusse F, Garcia-Mina JM, Yvin JC, Ourry A (2013). Brassica napus growth is promoted by Ascophyllum nodosum (L.) Le Jol. Seaweed extract: microarray analysis and physiological characterization of $\mathrm{N}, \mathrm{C}$, and S metabolisms. Journal of Plant Growth Regulation 32:31-52.

Khan W, Rayirath UP, Subramanian S, Jithesh MN, Rayorath P, Hodges DM, Critchley AT, Craigie JS, Norrie J, Prithivira B (2009). Seaweed extracts as biostimulants of plant growth and development. Journal of Plant Growth Regulation 28(4):386-399.

Lawlor DW, Tezara W (2009). Causes of decreased photosynthetic rate and metabolic capacity in water-deficient leaf cells: a critical evaluation of mechanisms and integration of processes. Annals of Botany 103:1-19.

Ma P, Bai T, Wang X, Ma F (2015). Effect of light intensity on photosynthesis and photoprotective mechanisms in apple under progressive drought. Journal of Integrative Agriculture 14:1755-1766.

Maini P (2006). The experience of the first biostimulant, based on amino acids and peptides: a short retrospective review on the laboratory researches and the practical results. Fertilitas Agrorum 1:29-43. 
202

Mikiciuk M, Dobrolmilska R (2014). Assessment of yield and physiological indices of small-sized tomato cv. 'Bianka F1' under the influence of biostimulators of marine algae origin. Acta Scientarum Polonorum Hortorum Cultus 13:31-41.

Miyashita K, Tanakamaru S, Maitani T, Kimura K (2005). Recovery responses of photosynthesis, transpiration, and stomatal conductance in kidney bean following drought stress. Environmental and Experimental Botany 53:205-214.

Pirzad A., Mohammad Reza Shakiba MR, Zehtab-Salmasi S, Abolghasem S, Mohammadi SA, Reza Darvishzadeh R, Samadi A (2011). Effect of water stress on leaf relative water content, chlorophyll, proline and soluble carbohydrates in Matricaria chamomilla L. Journal of Medicinal Plants Research 5:2483-2488.

Pramod K, Dube SD, Chauhan VS (2000). Photosynthetic response of bell pepper to biozyme in relation to fruit yield. Vegetable Science 27:54-56.

Rahbarian R, Khavari-Nejad R, Ganjeali A, Bagheri A, Najafi F (2011). Drought stress effects on photosynthesis chlorophyll fluorescence and water relations in tolerant and susceptible chickpea (Cicer arietinum L.). Acta Biologica Cracoviensis series Botanica 53:47-56.

Reed RH, Davison IR, Chudek JA, Foster R (1985). The osmotic role of mannitol in the Phaeophyta: an appraisal. Phycologia 24:35-47.

Shao HB, Chu LY, Cheruth AJ, Zhao CX (2008). Water-deficit stressinduced anatomical changes in higher plants, C. R. Biologies 331:215-225.

Shehata SM, Abdel-Azem HS, Abou El-Yazied AA, El-Gizawy AM (2011). Effect of foliar spraying with amino acids and seaweed extract on growth chemical constitutes, yield and its quality of celeriac plant. European Journal of Scientific Research 58:257-265.

Sikuku PA, Netondo GW, Onyango JC, Musyimi DM (2010). Chlorophyll fluorescence, protein and chlorophyll content of three NERICA rainfed rice varieties under varying irrigation regimes. ARPN Journal of Agricultural and Biological Science 5:19-25.

Souza RP, Machado EC, Silva JAB, Lagoa AMMA, Silveira JAG (2004). Photosynthetic gas exchange, chlorophyll fluorescence and some associated metabolic changes in cowpea (Vigna unguiculata) during water stress and recovery. Environmental and Experimental Botany 51:45-56.

Spinelli F, Fiori G, Noferini M, Sprocatti M, Costa G (2009). Perspectives on the use of a seaweed extract to moderate the negative effects of alternate bearing in apple trees. The Journal of Horticultural Science and Biotechnology 84:131-137.
Subrahmanyam D, Subash N, Haris A, Sikka AK (2006). Influence of water stress on leaf photosynthetic characteristics in wheat cultivars differing in their susceptibility to drought. Photosynthetica 44 (1):125-129.

Thirumaran G, Arumugam M, Arumugam R, Anantharaman P (2009). Effect of Seaweed Liquid Fertilizer on Growth and Pigment Concentration of Cyamopsis tetrogonolaba (L) Taub. AmericanEurasian Journal of Agronomy 2 (2): 50-56.

Ugarte RA, Sharp G, Moore B (2006). Changes in the brown seaweed Ascophyllum nodosum (L.) Le Jol. Plant morphology and biomass produced by cutter rake harvests in southern New Brunswick, Canada. Journal of Applied Phycology 18:351-359.

Wally OSD, Critchley AT, Hiltz D, Craigie JS, Han X, Zaharia LI, Abrams SR, Prithiviraj B (2013). Regulation of phytohormone biosynthesis and accumulation in Arabidopsis following treatment with commercial extract from the marine macroalga Ascophyllum nodosum. Journal of Plant Growth Regulation 32:324-339.

Warren CR, Livingston NJ, Turpin DH (2004). Water stress decreases the transfer conductance of Douglas-fir (Pseudotsuga menziesii) seedlings. Tree Physiology 24(9):971-979.

Whapham, CA, Blunden G, Jenkins T. Wankins SD (1993). Significance of betanines in the increased chlorophyll content of plants treated with seaweed extract. Applied Phycology 5: 231-234.

Wu H, Wu X, LiZ, Duan L, Zhang M (2012). Physiological evaluation of drought stress tolerance and recovery in cauliflower (Brassica oleracea L.) Seedlings treated with methyl jasmonate and coronatine. Journal of Plant Growth Regulation 31:113-123.

Xu C, Leskovar DI (2015). Effect of $A$. nodosum extracts on spinach growth, physiology and nutrition value under drought stress. Scientia Horticulturae 183:39-47.

Yordanov I, Velikova V, Tsonev T (2000). Plant responses to drought, acclimation, and stress tolerance. Photosynthetica 38(2):171-186.

Zavaleta-Mancera HA, Lopez-Delgado H, Loza-Tavera H, MoraHerrera M, Trevilla-Garcia C, Vargas-Suarez M, Ougham H (2007). Cytokinin promotes catalase and ascorbate peroxidase activities and preserves the chloroplast integrity during darksenescence. Journal of Plant Physiology 164:1572-1582.

Zlatev Z, Yordanov IT (2004). Effects of soil drought on photosynthesis and chlorophyll fluorescence in bean plants. Bulgarian Journal of Plant Physiology 30:3-18. 